\title{
The Wicked Problem the Water Framework Directive Cannot Solve. The Governance Approach in Dealing with Pollution of Nutrients in Surface Water in the Netherlands, Flanders, Lower Saxony, Denmark and Ireland
}

\author{
Mark Wiering ${ }^{1, *}$, Duncan Liefferink ${ }^{2}$, Daan Boezeman ${ }^{3}$, Maria Kaufmann ${ }^{2}$, Ann Crabbé 4 (D) \\ and Nanda Kurstjens ${ }^{5}$ \\ 1 Institute for Management Research, Department of Geography, Planning and Environment, \\ Radboud University (Nijmegen), 6500 HK Nijmegen , The Netherlands \\ 2 Institute for Management Research, Department of Geography, Planning and Environment, Radboud \\ University, 6500 HK Nijmegen, The Netherlands; d.liefferink@fm.ru.nl (D.L.); m.kaufmann@fm.ru.nl (M.K.) \\ 3 Netherlands Environmental Assessment Agency (PBL), The Hague, The Netherlands \& Institute for \\ Management Research, Department of Geography, Planning and Environment, Radboud University, \\ 6500 HK Nijmegen, The Netherlands; daan.boezeman@pbl.nl \\ 4 Centre for Research on Environmental and Social Change (CRESC), University of Antwerp, \\ 2000 Antwerpen, Belgium; ann.crabbe@uantwerpen.be \\ 5 Corporate Accounts, Renewi, 5928 PE Venlo, The Netherlands; nandakurstjens@live.nl \\ * Correspondence: m.wiering@fm.ru.nl; Tel.: +31-24-3615567
}

Received: 16 February 2020; Accepted: 17 April 2020; Published: 26 April 2020 updates

\begin{abstract}
The Water Framework Directive (WFD) is typically a framework directive that tries to encourage integration of policies for water quality and agriculture. Nutrients (nitrates, phosphates) from agricultural sources remain a 'wicked problem' in realizing the aims of the WFD, partly because the directive has to rely on other, neighboring policies to tackle to problem pressure of nutrients; it seems to lack instruments and measures to directly intervene in relevant agricultural policies. This contribution describes the different governance approaches of five member states and regions (The Netherlands, Flanders in Belgium, Lower Saxony- in Germany, Denmark and Ireland) to the nutrients problem and specifically focuses on the relationship between the nature of governance and the nature of measures taken. On the one hand, countries can vary in terms of a more consensual or antagonistic approach to dealing with water quality and diffuse pollution by agriculture, and emphasize more integration or separation in organization and programs. On the other hand, they can vary in the 'outcomes' in terms of more source-based measures or effect-based measures and the emphasis in policy instruments used. This article is based on the screening of policy documents, 44 interviews and several (international) feedback workshops. We found a great variety in governance approaches, while the nature of measures, in terms of source-based and effect-based, is only slightly different. On closer inspection, there are interesting differences in the consensual or antagonist discourses and differences in the use of more mandatory instruments or area-based policies. In many countries, the major challenge is to strike a balance between taking source-based measures, where necessary, and accommodating the difficult situations farmers very often find themselves in, as the reduction of nutrients (as a source-based measure) use can lead to lower yields and higher costs for manure disposal.
\end{abstract}

Keywords: water governance; water framework directive; water quality; diffuse pollution; nutrients; policy integration; experimentalist governance 


\section{Introduction}

The Water Framework Directive (WFD; 2000/60/EC) is one of the most ambitious environmental Directives of the European Union and its implementation remains a major challenge [1-3]. The Directive establishes a framework for the protection of all inland surface water, ground water, coastal and transitional waters with the aim to enhance the status of aquatic ecosystems, as well as the terrestrial ecosystems and wetlands that are depending on these systems. In short, the WFD is of crucial importance for the quest for clean and healthy water for humans, as well as for the quality of water ecosystems all over Europe. A fundamental policy change of the comprehensive WFD-besides integration of a series of many other former directives (Nitrates Directive, Urban Waste Water Treatment Directive, Drinking Water Directive, etc.) - is to pursue ecological goals for all waters (biological targets), rather than specified environmental health or nature conservation goals (certain conditions for specific habitats or functions or regulation for bathing, drinking). Next to this, the principle of 'no detoriation' is important, even with regard to cleaner water bodies. Building on these former Directives, the WFD aims to ensure ongoing substantial investments in water protection measures and water ecology. Possible measures range from improving sewerage systems, water purification, cleaning of rivers, ponds and brooks, the meandering of watercourses, building fish traps to the creation of buffer strips for manure and pesticides.

Nutrients (nitrates and phosphates) from diffuse agricultural sources remain a key problem pressure across Europe to realize the WFD goals [4]. Addressing those non-point sources is considered among the most 'intractable' (e.g., [5]) or 'wicked' (e.g., [6]) dimensions in the water governance literature. The place-based concentration of those sources and differing vulnerability of water ecosystems render uniform policy responses often ineffective. Understanding the differences in the way member states address diffuse sources is key for more successful policy responses. The Water Framework Directive has attracted substantial attention from scholars of comparative governance with regard to differences in formal and practical implementation [7-10], the organization of participation [11-13], issues of spatial fit and multi-level governance [13,14] or the improvement of methods, assessment systems and monitoring [15]. Surprisingly, however, comparative studies of governance strategies and practical measures dealing with diffuse agricultural sources, in relation to the WFD are limited, and single-country studies dominate (e.g., [16-18]). Nevertheless, a number of comparative studies and reports focus on the implementation of the Nitrates Directive [19-21] and there are studies signaling the problem of agricultural diffuse pollution in light of the WFD in an early stage [22].

One of the elements of wickedness of the problem is the coordination of policies that fall under the WFD [23]. The WFD integrates other Directives dealing with water quality, e.g., the Nitrates Directive (ND, 1991/676/EEC). This Directive aims to promote good farming practices, in order to protect groundwater and surface water from nitrate pollution and sets specific standards, e.g., for the application of fertilizers. While, integrated as an important part of the WFD, compliance with the Nitrates Directive is not necessarily sufficient to address all agricultural nutrient pollution in water bodies and reach the WFD objective of a 'good ecological status' of a variety of water bodies. First, the emphasis of the Nitrates Directive is largely on nitrates in ground water pollution, and less so, on nitrates and phosphates in surface water. Second, although, reducing eutrophication of surface waters is a goal under the Nitrates Directive, its rough and wide standards for surface water are not geared to achieving the goals of the WFD (see Section 2). The WFD can therefore refer to the Nitrates Directive when it comes to issues of diffuse pollution and eutrophication. However, member states may have to take additional measures to improve the status of aquatic ecosystems-or to prevent further deterioration (Article 11 (3:h) of the WFD states that Member States must take measures to prevent or control the input of pollutants from diffuse sources. The provision also regulates those measures and requires that they are periodically reviewed) while, the WFD itself does not provide instruments to address the agricultural sources of nutrients pollution.

Another element of the wickedness is the need to integrate water policy objectives in other sectoral policies, such as the Common Agricultural Policy (CAP). The CAP offers three instruments to 
address water quality needs: Cross-compliance for direct payments, additional greening payments and rural development funds. However, evaluations of the European Court of Auditors concluded that cross-compliance and rural development were only partly successful [24] and the greening payments were ineffective [25] to deliver on environmental objectives. While, reforms started off with high ambitions, successful lobbying watered down the requirements for farmers during implementation by the Member States [26]. Hence, while the need for policy integration is firmly on the water policy agenda for a few decades, the realities of realizing those objectives proved stubborn. Taken together, a governance problem arises in implementing the WFD. Nutrients are a crucial part of the physico-chemical status of water bodies, and are therefore, very important for the ecology of aquatic systems. Water managers can take measures to mitigate the effects of an overload of nutrients from agriculture, sometimes leading to all sorts of provisions they can do themselves (de-phosphating, water purification, extra water supply to flush water courses) and these can be seen as end-of pipe measures. However, water managers often do not seem to have the competences to intervene directly with regard to sources of diffuse pollution and need other policies for this. In other words, the WFD, in itself (except for reference to the Nitrates Directive), is lacking direct measures to tackle the sources of agricultural pollution while other regulatory regimes are helpful but not helpful enough. Water managers seem to need collaboration with the agricultural interest groups and/or with agricultural policy representatives to take more comprehensive measures.

This raises questions on what governance strategies water managers in different EU member states adopt in addressing the wicked issue of nutrients from diffuse agricultural sources. Our core question is whether there a relationship between the governance approach in a country and the nature of measures and policy instruments chosen. The governance approach is roughly indicated as consensus-oriented or antagonistic and as integrated or segregated, in regard to environmental and agricultural policies. The nature of measures taken in a country are divided in source or effect-based measures and voluntary or mandatory measures. The policy instruments are divided in 'sermons, carrots and sticks' with an additional instrument of 'physical architecture'. This will be further elaborated in the next section. To explore this relationship, we selected EU member states with largely similar tensions and comparable problem pressure, but with differences in their governance approach. In this way, we could investigate the relationship between the governance approach and the nature of measures and policy instruments. In the northern European countries, including Denmark, Belgium/Flanders, the Netherlands, Germany/Niedersachsen and Ireland, the agricultural sector has a substantial role in realizing water goals. In this article we want to inform theories of (water) governance while exploring the relationship between governance approaches and the nature and use of policy instruments. There is actually a knowledge gap on whether different governance approaches (consensus or antagonismintegration or separation) also lead to specific use of instruments [27].

\section{Type of Measures, Policy Instruments and Governance Approaches}

The WFD is explicitly a Framework Directive that integrates a series of former EU water regulations and tries to induce the governance of aquatic ecosystems in EU member states with general normative and organizational principles. The general aim is to improve the ecological and chemical status of water bodies-or at least improve their ecological potential. Parts of the framework contain more specific norms and standards, e.g., the environmental quality standards of the Daughter Directive on Priority Substances (2013/39/EU) and some incorporated Directives have specific (older) standards (the standards for nitrate in ground water (max. $50 \mathrm{mg} \mathrm{NO}_{3} / \mathrm{L}$ ) and in surface water for drinking water were already part of the 1975 Drink Water Directive 75/440/EEG and the Drinking Water Directive of 1998 (98/83/EC)) that later became important part of the Nitrate Directive (91/676/EEC). Besides these relatively clear standards and the qualitative end-goals of realizing a good ecological status, the subsidiarity principle of the WFD leaves both goal setting, measure selection and policy instruments to the member states $[8,9,28]$. The Directive provides procedural tools, guidelines and principles for this process. On the one hand this approach grants discretion and also forces the member states to 
intensively discuss and decide over conditions and related measures for improving biological (fish, algae, macro fauna and water plants), hydro-morphological (e.g., river bank structure) physico-chemical (e.g., nutrients) or chemical (concentrations of water pollutants) quality of their water bodies, and describe pathways (including barriers and delays) toward realizing these end goals.

Hence, this implementation process is not arbitrary, in the sense of only voluntary or non-binding. The member states will be held accountable for their aims and targets in the process, by setting up control, inter-calibration and monitoring systems and report on their progress for the European Commission. In this sense, the WFD has great resemblance with so-called experimentalist governance [29]. This type of contemporary governance knows four elements that "are linked in an iterative cycle" [29]: (1) Relatively open framework goals and metrics; (2) high discretion for local actors; (3) frequent reporting on performance and participation in peer review; and (4) revision by a widening circle of actors of the initial goals, metrics and decision making procedures. The WFD and its Common Implementation Strategy (CIS) are even used as the exemplifying cases of an "experimentalist architecture" [29,30].

This process of enforced self-discipline is, though, considered contingent and contextual. For more exact values for nutrient levels that correspond to the ecological goals set (i.e., a good ecological status or good ecological potential), water managers in member states have developed their own assessment methods [28]. The accompanying standards for phosphates and nitrates to prevent eutrophication in surface water required under the WFD can be substantially lower than the limit values mentioned in the Nitrates Directive. Van Grinsven et al. (2016) for example show for the Netherlands that, depending on the water type, the nitrogen concentrations required for a 'good ecological status' can be a factor 2 to 10 lower than the fixed, uniform standards mentioned in the Nitrates Directive of no more than $50 \mathrm{mg} \mathrm{N}_{3} / \mathrm{L}$ in surface water intended for drinking water.

As well as asserting certain principles, methods and procedures, the WFD prescribes further detailing of its policies by way of planning (River Basin Management Plans; RBMP's) with programs of measures. The experimentalist and self-disciplining characteristics of the WFD lead to planning structures and lists of measures that are sometimes specific, and sometimes very open and vague. This obviously means that the implementation of the WFD is not a straightforward operation, in terms of policy instruments used. Some measures can be taken by water managers themselves, if the financial situation permits, but there are other measures where water managers are highly dependent on neighboring policy fields or on additional resources to entice stakeholders to take action. The experimentalist character however sets conditions of peer review and coordination too, and this is substantiated in the Common Implementation Strategy with guidelines by EU experts commissions (e.g., on eutrophication assessment), inter-calibration exercises, communication and coordination on monitoring (e.g., [31]).

Consequently, there is a variety of possible measures suitable for implementing the WFD (e.g., [10], that divide over several types of policy instruments. The choice of these measures is dependent on political decisions, capabilities (e.g., budgets) and scientific evidence and support. In any case, policy instruments are not 'neutral devices', but are very often political in nature [32,33] and also assessing the effects of policy instruments or policy mixes is far from unproblematic [34,35]. To give one example, reducing nutrients involves source-based or effect-based measures. Source-based measures, e.g., reducing the amount of manure applied to the soil through stricter application standards, have proven to be effective in improving the water quality in the long run [17], but further restrictions are politically and economically problematic, as they would imply costly measures for the farmer, e.g., in transport of manure or processing manure at the farm. Further reductions possibly affect crop production, as well as conditions of competition on the agricultural market. They would, therefore, require political support from a wide variety of actors, including farmers, agro-business and consumers. Effect-oriented measures, such as investing in technologies or management measures that 'clean up' nutrient levels in the aquatic environment, e.g., installations to remove nutrients from water or soil, adapting flows of polluted and less polluted water are politically more feasible but tend to transfer costs to the water quality manager and eventually to the general public, which, in fact, is not in accordance with one of 
the core principles of the WFD, the polluter pays principle (art. 9, WFD). It is, therefore, especially interesting to investigate the type of measures chosen in different governance (and political) settings. For lists of measures we can refer to Collins et al. [36] and annexes there.

Other important elements of implementing the WFD is the nature of measures, in terms of a mandatory or voluntary nature and who is paying for them. This leads to the choice of specific policy instruments and instrument mixes. A distinction is commonly made between 'sermons' (knowledge exchange, communication campaigns, voluntary guidance programs, social incentives), 'sticks' (regulation, formal rules, strict standards, increased enforcement), 'carrots' (subsidies, levies, financial and economic incentives) [37,38]. Over the years also 'physical architecture' is included as a separate category of policy instruments [35,39]. Given the technical measures, such as de-phosphatising and 'cleaning up' water bodies or soils, we include this category of measures taken by the relevant agencies themselves, named physical measures/direct provisioning, sometimes incentivized by European regulation.

We focus on certain categories as it is virtually impossible to discuss all measures for the WFD (and ND) and their background. We think that the governance approach in a country (in terms of consensus/antagonism and integration/separation of environmental and agricultural policies) might affect the nature of measures taken (effect or source-based; voluntary or mandatory). However, what kind patterns we will find is an empirical question. To further clarify our expectations, we first specify our research questions and then formulate two central assumptions.

1. What type of measures do member states generally take in the practical implementation of the WFD related to diffuse agricultural pollution by nutrients? We looked at relevant policy documents and programs and the general nature of measures taken.

2. What types of policy instruments are generally activated in WFD implementation processes related to diffuse agricultural pollution by nutrients? We distinguish four categories of policy instruments: Sticks, carrots, sermons and physical architecture (including direct provisioning).

3. What governance approach do member states take in dealing with the implementation of the WFD and this wicked problem of agricultural pollution related to nutrients? For the sake of clarity, we focused on integrated or separated policies for water and agriculture (multi-sector governance). This means we did not focus much on scale (multi-level governance) and participation (multi-actor governance) as this has been studied elsewhere in more detail (e.g., $[7,13,40])$. We specifically looked at the ways in connecting the (agricultural) nutrients management and water quality management in a consensual way—or not—and the way countries showed organizational integration and/or program -integration. In light of the 'experimentalist architecture' as sketched by Sabel and Zeitlin [29], we might perhaps expect novel and tailor made approaches to the nutrients- problem.

This leads to the core question of our research project: Is there a relationship between the governance approach in a country and the nature of measures and policy instruments chosen? (See Introduction).

Answering these questions is further structured by a set of assumptions:

Assumption A: A more consensual and integrated governance approach to the implementation of the WFD with integrated organizational responsibilities and joint programs (addressing water management ánd agriculture) leads to a more comprehensive set of measures and thus leads to a higher chance of taking source- based measures.

Assumption B: A more antagonistic and separated governance approach to the implementation of the WFD, with separated organizational responsibilities and separated programs, leads to a higher chance of taking effect- based measures, including technical 'end of pipe' - measures taken by water managers.

The above assumptions are grounded both, in our own (longitudinal) empirical work, as well as in theories on implementation and policy styles. Inductively, we came across different governance approaches while comparing the WFD implementation in European member states $[10,40]$ and we were empirically interested in how these approaches were connected to the nature of measures and types of instruments, as investigated. More deductively, we were inspired by the work of Richardson, 
Gustaffsson and Jordan [41] and Van Waarden [42] on national policy styles. In the pioneering work of Richardson et al. [41] on policy styles the dimension of 'consensus versus imposition' was put central (next to proactive and reactive) and in his typology of national regulatory styles Van Waarden [42] juxtaposes a 'consensual' to a 'adversarial' dimension in regulatory style. We were especially interested in the latter dimension as it fits the conceptualising of the interactions between water management and the agricultural sector, next to the integration and separation-dimension. Therefore, we operationalised and typified the governance approach as follows: There is a strong role of joint policy making (at least) between the two sectors-showing a more consensual relationship or there are antagonistic, conflicting relations, showing a more antagonistic relationship in governance. Next to this we made a division between integration and separation, with two indicators: There is organizational integration or separation (more specifically looking at joint versus separated ministries dealing with water management and agriculture) and there is an important joint programme for water and agriculture-or there are separated programmes (referring to programme integration)—this is indicated in Table 1 (Section 5).

We formulated assumptions in order to clearly investigate the relationships between the interactions between the sectors (water management and the agricultural sector) and the nature of policy outcomes (in terms of policy instruments and the nature of measures). The role (and promise) of integrated governance is emphasized by Visseren-Hamakers [43] and Weitz et al. [44], the latter expecting integrative governance to be more effective, e.g., to improve cost-effectiveness and resource use efficiency, and to open up new business opportunities. We have pushed this idea by relating integrative governance approaches to certain outcomes, in terms of source-based and effect-based measures. If integrative governance is indeed synergetic and would lead to more effective measures, we would also expect it to include source-based measures, as these are generally considered to be effective measures. However, no strong theories can support our assumptions yet, as there is a knowledge gap on whether different jurisdictions lead to certain preferences for sets of instruments, as Capano and Howlett [27] recently have acknowledged.

These research questions and assumptions will be answered and tested in Section 4, but first we will explain our research design and methods.

\section{Research Design and Methods}

\subsection{Case Selection}

This research consisted of three consecutive research steps: a quick-scan, in-depth research and valorization. In the first phase of the research project, we performed a quick scan of five countries, next to the Netherlands, that would be potentially interesting for the implementation of the WFD. These countries were Denmark, Germany, Belgium, Austria and Ireland. We could not timely collect sufficient information on Austria. The four other member states or regions were selected for further elaboration in a second phase of research. We decided to focus on the regional state of Lower Saxony in Germany and Flanders in Belgium in order to be able to give more in-depth study of the implementation and measures.

The five countries were selected because they are characterized by similar ecological circumstances and problem pressure, i.e., diffuse nutrient pollution through intensive livestock industry. It must be noted that Ireland has, in light of the standards for nitrates in groundwater, less problem pressure, but Ireland wants to preserve its water quality with expanding agriculture, and therefore 'no detoriation' in light of the WFD is one of the core aims of this member state.

In addition to problem pressure and acknowledgment of the importance of the nutrients problem, we expected to find interesting differences in the governance approach: Some member states are more inclined towards multi-sector integration and others towards mono-sector functional separation. The Netherlands, for example, has strong sectoral and functional institutions specifically tasked with water management (regional water authorities, national water agency), while other member states 
strive towards different forms of multi-sector integration (e.g., the aquatic environment programs of Denmark, the Commission on integrated Water Policy in Flanders and the consensual approach with regard to the WFD and agricultural policies in Ireland).

For these kind of governance characteristics, it is obviously important to consider if the regional level in Germany (Länder level of Lower Saxony) and Belgium (region of Flanders) is comparable to the national level in The Netherlands, Denmark and Ireland. Although there are differences, we can conclude that the responsibilities undertaken in nations and Länder/regions are largely comparable. Flanders has important responsibilities in both water management and environmental-agricultural policies (manure policy) and for Germany holds that the Land level has the responsibility to take effect-based and source-based measures. The federal level in Germany sets the legal frameworks for implementing the Water Framework Directive, i.e., the Federal Water Law (Wasserhaushaltsgesetz) and for operational issues, e.g., the Fertiliser Ordinance (Düngeverordnung). The Länder, however, have the competence for operational implementation. They develop Länder-specific legislation, i.e., specify goals, measures and organizational structures, within the boundaries of the federal frameworks (for a comprehensive overview see [22]). In the context of the Updated Fertiliser Ordinance, the Länder receive more autonomy to implement stricter regulations: They can choose from a list of measures pre-defined by the federal level. Hence, for Germany, we considered both federal and Länder-specific legislation.

\subsection{Data Collection}

The main documents that were studied included the most recent River Basin Management Plans (2015-2021) of the selected countries (or regions). The implementation of the WFD is coupled to other directives, such as the Nitrate Directive, which forms a relevant and important part of the Basic Measures package of the WFD. Hence, we analyzed domestic measures reported within the Action Plans for the Nitrate Directive and comparisons thereof in a later stage [20,21]. In addition we looked at measures and instruments, based upon additional programs related to agricultural pollution specific for the WFD ('Secondary Measures'), e.g., subsidy programs relevant for the nutrients problem, guidance programs, (source-based) formal rules and regulation or technical or physical measures. In addition, we consulted the reports of the European Commission on the WFD implementation and additionally more detailed regional water plans as illustrations, for example, water household plans of regional water authorities in the Netherlands. Moreover, relevant academic literature on WFD implementation was studied.

Interviewees with policy makers and stakeholders were held in four countries in the period from February to March 2018 and in the period from October to January 2018/2019 for the Netherlands. Four to seven interviewees per country were selected (Appendix A) and more than twenty for the Netherlands (Appendix C). For all countries in the first round of country comparison, the interviewees included the responsible ministry or ministries (e.g., Environment, Agriculture, Food), the relevant executive branch or branches of these ministries, the main farmers' organization as well as the environmental/nature organization involved. The interview guide was based on our theoretical framework and covered following topics: problem pressure, policy instruments and governance arrangements. Drafts of the empirical country sections were sent to the respective respondents for feedback. Due to the controversialist character, particularly of the nutrients problem in some of the sample countries, several respondents were prepared to participate only under the condition of confidentiality. For this reason, interviews and respondents in workshops are referred to only in general terms (Appendices A-D).

After the empirical data collection and analysis, we organized a practitioners workshops with governmental officials of the countries and international scholars (except for Ireland) to validate our findings and facilitate the comparison (Appendix B). Finally, we asked practitioners and the Netherlands Environmental Assessment Agency (see acknowledgements) to give feedback on the end-reports (Appendices B and D). 
To systematically conduct the comparison, we collected information on: (1) Types of measures and types of policy instruments based on 'Basic Measures' (see above), (2) measures and instruments based upon additional programs related to agricultural pollution specific for the WFD ('Secondary Measures'). Then, we typified (3) the general governance approach and organizational structures in a country, focusing on consensual (a strong role of joint policy making and emphasizing co-responsibility) or antagonistic (rather detached decision making or even conflicting relationships) and (multi-sector, agriculture and water management) integration or separation in organization and in programs (see Table 1).

\section{Results in Five Member States}

\subsection{Flanders}

In the federal state of Belgium, the regions are responsible for environmental policy-making, including developing policies implementing the WFD and the ND. Although, environmental pressures from intensive agricultural activities are high in the densely-populated and strongly urbanized region, the generally applied policy style aims to reconcile environmental and economic goals simultaneously. The state-of-the-environment reports report on stabilizing or even deteriorating water quality [45,46], which is not effectively dealt with, due to insufficiently stringent policy measures.

Governance structures facilitate close collaboration between environmental agencies, the agricultural department and farmers' interest groups. In Flanders, the Flemish Land Agency-an executive agency associated to the ministerial department for the environment-is responsible for implementing Flemish manure policies, which reflects a strong integration of manure policies in the environmental policy domain. Furthermore, the Ministerial Department for Agriculture is member of the Coordination commission on Integrated Water policy (CIW), a multi-level and multisector administrative platform that is responsible for drafting the WFD's river basin management plans. The ministerial department for agriculture and farmers' interest groups have close links with the Minister(s) for Environment and Agriculture, assisting them in high-level decision-making.

The entire Flemish territory has been designated as vulnerable area under the ND. In the second Flemish RBMPs (2016-2021) specific areas with insufficient surface water quality were designated as, respectively, 'speerpuntgebieden' (spearhead areas) or 'aandachtsgebieden' (attention areas). The goal is to reach the good status in 2021 within the 17 spearhead areas and in 2027 within the 56 attention areas.

Spatial differentiation occurs in addition to temporal differentiation via spearhead and attention areas. Areas where nitrate concentrations in the surface water exceed the norm of $50 \mathrm{mg} \mathrm{NO} / \mathrm{L}$ or where the evolution of the nitrate concentration in groundwater shows insufficient progress are qualified as focus areas (focusgebieden). In the former Manure Action Plan 5 (MAP5, 2015-2019), farmers having more than $50 \%$ of their farmland within such a focus area became a 'focus farm by location' and faced additional requirements to reduce nitrate leaching from arable land without any financial compenation in return. This means that there is a mandatory regime including stricter source-based measures (e.g., with regard to the norm of $50 \mathrm{mg} \mathrm{NO}_{3} / \mathrm{L}$ for ground water) in focus areas. The focus area-approach still exists, but in view of the administrative burden of determining the exact area-boundaries for farmers, in MAP6 (2019) larger areas are now under a stricter regime.

Manure policy in Flanders relies to a relatively large extent on regulation and enforcement. It has a business-oriented approach to control and enforce compliance. Since MAP5, the maximum application standard is $170 \mathrm{~kg} / \mathrm{ha}$, but this standard is differentiated per soil type and crop. For determining the maximum application standard, a farm-based approach is used. Derogation per parcel is possible, as long as the standard on farm-level is not exceeded. In 2018, 2.800 farms made use of the derogation on 94.000 ha (14.5\%) of agricultural land, particularly for grass and corn crops.

Besides this detailed regulatory approach ('sticks'), there is also room for targeted advice to farmers ('sermons'). Until recently, this task was performed by the state consultancy agency (Bedriffsadvies Vlaamse Landmaatschappij), a part of the Flemish Land Agency. After its abolishment in 2018, the task 
was largely taken over by a private Coordination Centre aimed at guiding farmers in the field of sustainable fertilizer use (interview Flanders, Coördinatiecentrum Voorlichting en Begeleiding duurzame Bemesting (CVBB), February, 2018).

Next to 'sticks' and 'sermons', voluntary policy schemes accompanied by subsidies ('carrots') exist. A common subsidy is the management contract (beheersovereenkomst), part of the EU Regional Development Programme (RDP). In recent years, farmers have become more reluctant to make use of this instrument. Farmers who are interested in compensation for buffer zones are worried that in their 'green zones' rare vegetation will grow with accompanying consequences related to the EU Habitats Directive. Second, a reform of the program a few years ago has made conditions for obtaining a contract considerably more stringent.

\subsection{Denmark}

Policies regarding the pollution of surface waters by nutrients from agriculture have a long history in Denmark, starting with the Plan for the Aquatic Environment of 1987 [47] (Andersen 1997). On this basis, the process of implementing the WFD in Denmark started out in the 2000s with relatively high ambitions. After some years, cost-effectiveness took over an increasing role in the debate and a gradual shift in emphasis from mandatory to more voluntary policy schemes could be observed $[8,10,48,49]$.

Two turning points epitomize this shift. Around 2009, growing concern in the powerful agricultural sector about the costs of WFD-related measures, problems in living up to the deadlines set by the WFD (Denmark was late in submitting the first round of RBMPs), as well as the economic crisis, led to increasingly antagonistic relations between the agricultural sector and the government $[8,10,50]$. This development culminated in the establishment of a radical farmers organization (somewhat ironically called 'Sustainable Agriculture') in 2010 and several court cases against the new Buffer Zone Act which eventually led to the Act's withdrawal in 2015 [51].

Second, a new liberal minority government came into office in 2015. Its Food and Agriculture Package put strong emphasis on the economic feasibility of the agricultural sector. Apart from heading for more spatial differentiation of measures, it replaced the mandatory scheme for additional catch crops by a voluntary scheme, abandoned the mandatory buffer zones along watercourses and relaxed the maximum amount of livestock manure to be applied to the land (The maximum amount of nitrogen contained in manure from pig, poultry and fur animal farming applied to the land used to be $140 \mathrm{~kg}$ $\mathrm{N} /$ ha/year in the period 2002-2017. From 2017, this was relaxed to $170 \mathrm{~kg} \mathrm{~N} / \mathrm{ha} /$ year, which is in line with the EU Nitrate Directive (Ministry of Environment and Food/EPA 2017).) [10,48,52,53].

From the first Plan for the Aquatic Environment in 1987, Danish policies in the field of water, nature and agriculture have been characterized by a high degree of sector integration. In the Danish Environmental Objectives Act of 2003, the implementation of the WFD and the EU's Birds and Habitats Directives was combined [7]. The 2015 liberal government merged the two ministries formerly responsible for environment and agriculture into one integrated Ministry of Environment and Food, although, it does not necessarily leading to stronger environmental and water policies.

Nowadays, Danish policy for nutrients from agriculture follows what might be called a 'hybrid model' of stick, carrots and sermons. Nationally formulated, source-oriented obligatory standards for the application of nitrogen to the land form the basis. Additional and mostly effect-oriented measures, such as the cultivation of catch crops and the establishment of mini-wetlands intended to act as nitrogen sinks, have a more voluntary character while being stimulated with the help of a combination targeted advice and subsidy schemes [10,48].

\subsection{The Netherlands}

The Netherlands, a downstream country characterized by intensive farming and a large livestock sector, has a long history with water quality problems. Policy responses since the 1980s and 1990, both for farming and urban wastewater, have substantially lowered nutrient concentrations of Dutch waters. However, progress is stagnating since 2009 [54]. Taking into account regional differences [55], nitrogen 
and phosphorus leaching and runoff from agricultural land should be roughly halved nationally in order to meet the nutrient limit values for surface waters that correspond to the WFD's requirements.

Two political processes are particularly important to understand the Dutch governance approach of diffuse agricultural pollution and the WFD. First, water and agricultural domains are traditionally strongly separated. In the first years of implementing the WFD, the potential consequences for agriculture have led to an upsurge in political attention to the directive [8,56]. In 2004 a 'pragmatic stance' was adopted tampering ambitions for designated water bodies. In 2007, a political decision (an amendment in Dutch Parliament of Van der Vlies c.s. [57]) the WFD was determined not to add further costs for farmers beyond the obligations resulting from the ND. This led to increasing debate about whether agriculture was responsible to meet the more ambitious WFD norms for nutrients than the $50 \mathrm{mg} \mathrm{NO}_{3} / \mathrm{L}$ mentioned in the ND (e.g., interviews The Netherlands, Program Bureau KRW-DHZ, 11 September 2018) $[17,58]$. Nevertheless, in 2016, a new national water policy approach was adopted in which 'diffuse agricultural sources' was one of the two priority topics, signaling the pressure for a better integration of the agricultural and water domains.

Second, over the last decades, the agricultural domain has witnessed fundamental institutional change $[59,60]$. While, its policy style has remained consensual, its corporatist institutions and development instruments have been rolled back with the state focusing on its environmental regulatory tasks. However, agricultural remained a powerful political interest, whereas the state turned towards an increasing fine-tuning of regulation, in order to reconcile economic development with environmental goals [61].

The two processes have resulted in a hybrid policy approach, combining a mandatory and a voluntary track. The mandatory track includes source-based standards under the national manure regulation. Subsequent Nitrate Action Plans have tightened application regulations and standards (i.e., in some exceptional cases lower than $170 \mathrm{~kg}$ nitrate/ha from manure for crops with a high risk of nitrate leaching), while differentiating them according to region, soil type, crop type, sometimes even crop variety, and the phosphor condition of the soil [62]. In addition, following article 5.5 of the ND, the Netherlands introduced further regulatory measures, e.g., production rights that de facto cap total manure production and regulations to balance the manure market, such as manure processing and transport obligations.

The voluntary approach centers around the Delta Plan Agricultural Water Management. Under the threat of additional mandatory measures, this largely publicly funded programme was initiated by the farmers' organizations in 2016. It contains both carrots and sermons, involving for instance good agricultural practices and subsidies for implementing techniques. Also, regional governments sometimes fund additional water measures such as broader manure-free zones. At the same time, the regional water authorities invest in direct provisioning of lower nutrient levels, i.e., by improving wastewater treatment plants above mandatory standards, changing water supply routes in canals and, occasionally, installations to remove phosphate from the water. These measures belong to the category of 'physical architecture' as a policy instrument.

Taken together, the Netherlands is characterized by fragmentation between the agricultural and water policy domains. While still consensus-based, agri-environmental regulation is becoming both stricter and more differentiated in terms of crop production (although, not in terms of area differentiation like in the Flanders situation). Moreover, this fragmentation yielded RBMPs in which the water authorities aim at monitoring and realizing the WFD goals, but address agricultural sources only indirectly by providing funding for additional voluntary measures and direct provisioning of water treatment.

\subsection{Ireland}

Ireland has a relatively extensive farming sector with a large role for cattle grazing. It wants to preserve its green image and nature and environment is considered important, while at the same time having a growth strategy in agriculture (named FoodWise). Water quality is considered not only in 
terms of the effects caused by agriculture, but rather as a condition for the responsible development of agriculture (interview policy advisor Ministry of Housing, Planning and Local Government, March 2018).

After having tried a regional approach that was not backed up with sufficient resources [63-65]. Ireland quite radically changed its approach around 2016 [66]. Official districts in Ireland were merged to form one national River Basin District and responsible authorities set up a three-tier approach consisting of: (1) the new Water Policy Advisory Committee, a relatively multi-sector and independent national level forum; (2) continuation of the strong role of the Environmental Protection Agency (EPA) in policy making, funding, data collection and monitoring; and (3) the new Local Authorities and Communities Office (LAWCO) [67].

Furthermore, the challenges of the WFD (and the ND) are taken up by a strong broad collaboration between four key players, the Ministry for Housing, Planning and Local Government, the Department of Agriculture, Food and the Marine, the EPA and an agricultural knowledge institute, the Agriculture and Food Development Authority (Teagasc) with an array of other departments and NGO's (Interviews policy advisors Ministry, March 2018) [67,68]. Also on the regional level, the approach is collaborative and consensual, with the new LAWCO playing an important role in supporting local authorities and communities. The local monitoring system, as well as practical guidance is expected to strongly improve, with additional officers installed as 'stream walkers' and more advisors for farmers (Interviews Ireland March 2018). Nevertheless, the Irish approach is still relatively centralized, especially considering the existence of a single, nation-wide RBMP and the fact that domestic resources (budgets, knowledge, monitoring systems) normally originate from the Ministries or from the EPA, assisted by European funding (interviews Ireland, EPA, March 2018; Regional coordinator Waters and Communities Officers (LAWCO), March 2018 and Ministry of Housing, Planning and Local Government, March 2018).

Regarding source based measures, we did not find mandatory deviations from the general manure application norm of $170 \mathrm{~kg} \mathrm{~N} /$ ha of livestock manure. Irish derogation levels for grassland are also not far from levels in other derogation countries (see [20,21]).

Ireland has a lot of subsidized programs for guidance of fertilisers use and other voluntary measures. In a series of Agricultural Catchment Programmes, fertilizer use is monitored with pilots wherein lower standards than $50 \mathrm{mg} \mathrm{NO} / \mathrm{L}$ can apply. Ireland was one of a minority of EU member states to include direct control of chemical phosphorus (P) fertilizers in the Nitrates Directive National Action Plan of 2006 [69]. The Green Low Carbon Agri-environmental scheme (GLAS) is another key programme. It involves 1.4 billion euros and 48.800 farmers and contains research, guidance and subsidies for specific measures, e.g., restrictions for chemical fertilizers for areas of 'low input permanent pasture' (important in high status areas), and catch crops [69]. These programs are, in fact, part of the subsidy schemes under the EU's RDP 2014-2020, financed jointly by the EU and national government.

In conclusion, Ireland can be considered a country that 'puts its money on carrots and sermons' [10] and on voluntary source-based and effect-based measures. This strategy is based on strong collaboration between the ministries and agencies involved in the agricultural sector. Much is expected of co-responsibility of farmers and innovations in 'smart farming' [70].

\subsection{Lower Saxony}

In the German Land Lower Saxony, as compared to the other countries of this study, water and agricultural policies are less integrated and less consensual. There are no formal platforms or instruments at the level of the Land supporting integration and communication between water and agriculture. However, despite a historically strained relationship, communication has recently increased. In the past, particularly the federal, but to a lesser degree also the Länder ministries had an antagonistic relationship with little communication because their goals and interests appeared to be fundamentally different (water quality vs. agricultural development). At the same time, it is acknowledged that the objectives of the WFD cannot be reached without the contribution of agriculture, even though the river 
basin management plans are issued only by the environmental ministry. The 'Agro-environmental measures' (Agrarumweltmaßnahmen), for example, illustrate how subsidy instruments issued by the agricultural ministry address an explicit goal of the WFD. The updated Fertiliser Ordinance has been transposed in Lower Saxony legislation through cooperation of the two Länder ministries (Interviews Lower Saxony Feb/March 2018). On the local level, the two sectors cooperate more, for example in local area cooperations. However, the power and competencies are not balanced. Water managers, notably the environmental state agency NLWKN (Niedersächsischer Landesbetrieb für Wasserwirtschaft, Küsten- und Naturschutz) have little competence and local water associations are small and fragmented. The Chamber of Agriculture (Landwirtschaftskammer), in contrast, is an institutionalized and strong lobbying organization of the farmers, which indicates the historical power of the agricultural sector.

In Lower Saxony, a mix of instruments is applied to address diffuse nutrient pollution: regulatory instruments (e.g., Fertiliser Ordinance, Düngeverordnung), subsidies and consultation (e.g., Agrarumweltmaßnahmen and the drinking water cooperations, see below). Yet, the focus is mainly on voluntary and effect-based measures, e.g., subsidies and consultation, with little coercion (Interviews Lower Saxony February/March 2018 and [21]).

The standards for nitrate and phosphate in ground and drinking water are not more ambitious than indicated in the ND. Even more so, the Fertiliser Ordinance was criticized to give too little opportunity for enforcement due to limited inspections and insufficient sanctions in case of poor compliance [71]. Hence, the EU initiated an infringement procedure and the ordinance was updated. It now provides somewhat stricter manure application procedures and sets up automatized data collection and synchronization (\$ 13.6) to strengthen enforcement [72], but does not prescribe stricter application norms.

Voluntary measures include the drinking water cooperations or the EU's RDP (e.g., Agrarumweltmaßnahmen). These instruments provide consultation and finance voluntary source-and effect-based measures, for example: Reduction of fertilization or pesticide use, the transformation of agricultural areas in grassland, or catch crops [73] or, in the context of the RDP, cultivation of catch crops, buffer strips, etc. These measures may lead to reduced yields, in which case farmers are compensated for their loss in profit (Interviews Lower Saxony February/March 2018; [74]).

In conclusion, source-and effect-based measures are applied in Lower Saxony a mix of. However, the implementation of these measures is mainly voluntarily, which might reflect the lack of integration and limited consensual approach that could foster more ambitious instruments.

\section{Discussion}

In the previous section we have looked at the nature of measures that five member states generally take dealing with diffuse nutrients pollution from agriculture. We analyzed; (1) whether these measures are mostly source-based or effect-based; (2) which types of policy instruments (sticks, carrots, sermons and physical architecture (including direct provisioning)) were used to implement the measures; and (3) we attempted to relate this to the general governance approach, mainly concentrating on the dimension of consensus-oriented or antagonistic and integrated versus separated policies for water and agriculture.

What patterns did we find? Is there indeed a connection between consensual and integrated policies and the nature of measures? Our assumptions were that (assumption A) a more consensual, integrated governance approach would lead to a more comprehensive set of measures (both source-based and effect-based), and thus, a higher chance of taking source-based measures. In contrast, (assumption B) a more antagonistic and separated governance approach, where organizational responsibilities and programs are separated, lead to a higher chance of taking effect-based measures, including emphasis on more technical measures taken by water managers, in other words, using policy instruments dealing with the 'physical architecture'. 


\subsection{On the Nature of Measures}

Generally, we found that, there are remarkable differences in the governance approaches. However the type of measures taken in terms of basic measures (related to the Nitrates Directive) and secondary measures (extra programs for the WFD related to nutrients policies), were generally not that different. On the one hand, the decades long experience with and communication on basic measures from the ND lead to forms of horizontal coordination, or 'normative isomorphy' [74], between member states. In addition, many countries ran into trouble with the European Commission because of infringement procedures and discussion on derogation extensions. We observe patterns of 'coercive isomorphy' [75] over the years, as many countries (in all investigated member states except Ireland) were pressured to take firm action in realizing more tangible and practical programs of measures for the nutrients problem in light of both the ND and the WFD. On the other hand, many countries faced issues with respect to agricultural target groups, which sometimes led to softening programs again. In other words, the member states were 'sandwiched' between the ambitions of European Union and the pressure from farmers and agricultural lobbies. This probably led to more feasible and less intrusive measures being taken, such as having catch crops, that we see everywhere (Table 1). This also means that, generally speaking, more novel or experimental programs are difficult to maintain because of the political pressures of the 'sandwich' from the bottom up and the top down.

This being said, if we take a closer look, we still found some interesting patterns. In response to assumption $\mathrm{A}$, on the relation between consensual approaches, integration and a broader mix of measures we found that Ireland has a strongly consensual governance approach, (although no formal organizational integration on minister level) with friendly contacts between ministries and integration at program level, so we could expect a broader mix of measures, including those addressing agriculture at the basis. We indeed found a great variety of measures in many programs, and some more stringent source based measures (e.g., on reducing the use of chemical fertilizers in high status areas), but these were not mandatory and, as already stated, these were more feasible in a country with less urgent problem pressure. The part of the assumption A relating to 'more source based measures' could not be confirmed.

Flanders is a very interesting case where great problem pressure can go together with a relatively consensual governance approach and programmed integrated water management (although separate ministries involved). In Flanders, we see more mandatory, and also source-based measures in specific areas were the nutrients problem is most pressing (focus areas). Here, our assumption A was confirmed.

In the other countries, it is more difficult to clearly identify patterns. The relationships between policy domains in the Netherlands are generally consensual (the national 'polder model') but in water quality management the Netherlands chooses to have a very cautious approach towards agriculture, not so much consensual. Recently (2018-2019), there are more antagonistic relationships with agriculture on nutrients policies but also more public awareness that there are serious problems with nitrogen and phosphorus. The ministries are separated (even fragmented on the issue of nutrients) and the Dutch programs are not strongly integrated; we see cautious steps towards stricter source-based measures (only incidentally). Dutch WFD governance focusses rather on fine-tuning of regulations and effect-based measures, including technical 'end of pipe' measures, relating to physical architecture. Very recently, there are Dutch measures taken that deal with reducing livestock (first in relation to breaching phosphates production agreements with the EC after abandoning the milk quota and later in light of odor nuisance for pig farming). 
Table 1. Overview of governance characteristics and nature of measures in five countries.

\begin{tabular}{|c|c|c|c|c|c|c|}
\hline Countries/Themes & Indicators & Ireland & Flanders & The Netherlands & Lower Saxony & Denmark \\
\hline $\begin{array}{c}\text { Governance-consensus } \\
\text { or antagonistic? }\end{array}$ & $\begin{array}{c}\text { Strong role of joint policy } \\
\text { making and co-responsibility } \\
\text { OR antagonistic, } \\
\text { conflicting relationships }\end{array}$ & Strongly consensual & Consensual & $\begin{array}{l}\text { More cautious than } \\
\text { consensual, but lately } \\
\text { more antagonistic }\end{array}$ & $\begin{array}{l}\text { Antagonistic on higher } \\
\text { level (federal), more } \\
\text { consensual on } \\
\text { lower levels }\end{array}$ & $\begin{array}{l}\text { (Strongly) antagonistic } \\
\text { over the last years }\end{array}$ \\
\hline \multirow{2}{*}{$\begin{array}{c}\text { Governance-integrated } \\
\text { policies? }\end{array}$} & $\begin{array}{c}\text { Organizational integration of } \\
\text { water and agriculture }\end{array}$ & No (two ministries) & No (two ministries) & No (two ministries) & No (two ministries) & $\begin{array}{l}\text { Two ministries until 2015, } \\
\text { then merged into one }\end{array}$ \\
\hline & $\begin{array}{l}\text { Program integration of water } \\
\text { and agriculture }\end{array}$ & $\begin{array}{l}\text { Yes, strong emphasis on } \\
\text { cooperation in } \\
\text { national RBMP }\end{array}$ & $\begin{array}{l}\text { Yes, integrated } \\
\text { water policies }\end{array}$ & $\begin{array}{c}\text { No (separate } \\
\text { policy programs) }\end{array}$ & $\begin{array}{l}\text { No (separate } \\
\text { policy programs) }\end{array}$ & $\begin{array}{c}\text { Yes, Plans for } \\
\text { Aquatic Environment }\end{array}$ \\
\hline \multirow{4}{*}{$\begin{array}{l}\text { Mandatory source based } \\
\text { measures } \\
\text { Related to Basic Measures } \\
\text { (ND) } \\
\text { or related to } \\
\text { Supplementary measures }\end{array}$} & $\begin{array}{l}\text { Stricter standards than } \\
\text { regular ND } 50 \mathrm{mg} / \mathrm{L} \text { ? } \\
\text { (for groundwater or } \\
\text { surface water) }\end{array}$ & $\begin{array}{l}\text { No, voluntary, with some } \\
\text { pilots in Agricultural } \\
\text { catchment Programs } \\
\text { (with } 40 \mathrm{mg} / \mathrm{L} \text { ) }\end{array}$ & $\begin{array}{l}\text { Yes, in specific focus } \\
\text { areas and for certain } \\
\text { categories of } \\
\text { pollution of farmers }\end{array}$ & $\begin{array}{l}\text { No stricter standards than } 50 \\
\mathrm{mg} \mathrm{NO}_{3} / \text { for ground water, } \\
\text { with some very specific } \\
\text { exceptions for crops with } \\
\text { high risk leaching. }\end{array}$ & $\begin{array}{l}\text { No stricter standards } \\
\text { than } 50 \mathrm{mg} \mathrm{NO} / \mathrm{L} \text { for } \\
\text { ground water }\end{array}$ & $\begin{array}{c}\text { Yes, in low denitrification } \\
\text { areas } \\
\text { Stricter application } \\
\text { standards }(140 \mathrm{mg} / \mathrm{ha} / \mathrm{y}) \\
\text { but later relaxed }\end{array}$ \\
\hline & $\begin{array}{l}\text { Eutrophication policies } \\
\text { ND, obligatory }\end{array}$ & $\begin{array}{l}\text { Direct control of } \\
\text { chemical phosphorus }\end{array}$ & $\begin{array}{l}\text { Phosphates } \\
\text { norms regulated }\end{array}$ & $\begin{array}{l}\text { Phosphates norms and } \\
\text { general ceiling, because } \\
\text { of derogation }\end{array}$ & $\begin{array}{c}\text { Yes, extra measures } \\
\text { phosphates } \\
\text { sensitive areas }\end{array}$ & $\begin{array}{c}\text { Phosphates } \\
\text { norms regulated }\end{array}$ \\
\hline & Catch crops policies & Yes (GLAS) & Yes & Yes & Yes & $\begin{array}{l}\text { Yes, first mandatory, now } \\
\text { voluntary }\end{array}$ \\
\hline & $\begin{array}{c}\text { e.g., stricter standards in } \\
\text { additional programs for } \\
\text { water and agriculture or } \\
\text { additional programs } \\
\text { for nutrients }\end{array}$ & $\begin{array}{l}\text { No, voluntary programs } \\
\text { and measures, but large } \\
\text { adoption (GLAS) }\end{array}$ & $\begin{array}{l}\text { No, voluntary } \\
\text { measures }\end{array}$ & No, voluntary measures & $\begin{array}{l}\text { No, there are cooperative } \\
\text { programs, but these } \\
\text { are voluntary }\end{array}$ & $\begin{array}{l}\text { Difficult to say, because of } \\
\text { integrated policies }\end{array}$ \\
\hline $\begin{array}{l}\text { Mandatory effect based } \\
\text { measures Related to Basic } \\
\text { Measures (ND) } \\
\text { or Secondary } \\
\text { measures (WFD) }\end{array}$ & $\begin{array}{l}\text { - e.g., buffer zones } \\
\text { - wetlands } \\
\text { - heliofyten-filters }\end{array}$ & $\begin{array}{l}\text { No, voluntary, but large } \\
\text { adoption. e.g. fencing, } \\
\text { zoning, etc. }\end{array}$ & $\begin{array}{l}\text { Yes, Buffer zones of } \\
1 \mathrm{~m} \text { mandatory and } \\
\text { river banks policies, } \\
\text { but mostly voluntary } \\
\text { measures through } \\
\text { covenanting and } \\
\text { (European) subsidies }\end{array}$ & $\begin{array}{c}\text { Generally no, mostly } \\
\text { voluntary, but sometimes } \\
\text { mandatory, around } \\
\text { ecological valuable creeks. }\end{array}$ & $\begin{array}{l}\text { Yes, because of } \\
\text { infringement procedure } \\
\text { more pressure on } \\
\text { effect-based measures, } \\
\text { e.g., buffer zones } \\
\text { mandatory; incentives for } \\
\text { extensification in critical } \\
\text { agricultural areas. }\end{array}$ & $\begin{array}{l}\text { Yes and no, some } \\
\text { measures first mandatory, } \\
\text { however, later replaced } \\
\text { by voluntary schemes for } \\
\text { riparian zones; also } \\
\text { strong role } \\
\text { for mini-wetlands. }\end{array}$ \\
\hline $\begin{array}{c}\text { Strong role for } \\
\text { technical-'physical } \\
\text { architecture', e.g., water } \\
\text { treatment, } \\
\text { dephosphata-tion. }\end{array}$ & & No & $\begin{array}{l}\text { Yes, but mainly } \\
\text { financed/installed by } \\
\text { farmers themselves }\end{array}$ & $\begin{array}{l}\text { Yes, strong role for direct } \\
\text { provisioning of water } \\
\text { treatment/cleaning water } \\
\text { for nutrients }\end{array}$ & No & Yes \\
\hline
\end{tabular}


In Lower Saxony (Germany), we see more or less comparable tensions (to the Netherlands), however, antagonism is mostly on the federal level and on the regional or local level more consensus can be found; on the Länder level in Lower Saxony there are two ministries involved and programs are not well integrated. This conforms to the expectation that there is great emphasis on (voluntary regimes with choosing) effect-based measures (e.g., processing of manure) and less on source-based measures. The latter do not exceed the EU-standards, moreover, Germany has been criticized for weak enforcement of existing legislation. Assumption B is confirmed for the Netherlands and Lower Saxony, but previously mentioned, there is an emphasis on effect-based and voluntary measures in almost all countries.

Finally, in Denmark, there is a strong evolution of policies and some serious political turns were made in relevant agro-environmental policies. At the start, the Danes were ambitious with a perception of serious problem pressure and strong attempts to establish integrated programs. Indeed, source-based mandatory measures followed. At that time, assumption A was confirmed. However, in recent years, protest from the agricultural sector was translated politically and a more antagonistic sphere started to dominate the field. This led to a relaxing of various mandatory source-based measures, which now no longer deviated from the European standards. Instead, more emphasis was put on voluntary, effect-based measures, including mini-wetlands to filter water before it runs off to surface or ground water.

Remarkably, we found the measure of catch crops in all countries. This measure is less intrusive (in comparison to stricter manure standards or extensifying farms) and in some situation less costly, but considered effective, while the farmer generally has to pay for the catch crops. This measure could perhaps be seen as in-between source and effect-based.

\subsection{On the Nature of Policy Instruments}

In Section 4 we necessarily briefly, described the policy instruments that were given priority in the investigated countries. They could emphasize 'sermons' (e.g., knowledge exchange, voluntary guidance programs), 'sticks' (formal rules, stricter standards, increased enforcement), 'carrots' (subsidies, financial and economic incentives) or 'end of pipe' technical measures categorized as governing through 'physical architecture' (e.g., de-phosphatising and 'cleaning up' water bodies or soils). The comparison points out that, in most countries, there is an emphasis on voluntary measures and policy instruments related to guidance programs and knowledge exchange (sermons), mostly in effect-based measures, in combination with national and European subsidy programs, e.g., funds from the Rural Development Programs under the CAP (carrots). Interestingly, we observed that Member states predominantly used the voluntary, contractual agri-environmental schemes under the rural development funds (CAP's pillar 2), rather than using stricter standards for greening payments in order to meet water goals (CAP's pillar 1). This was strongest in Ireland, which uses a significant amount of European rural development fund for nature and the environment. The Dutch Delta Plan Agricultural Water Management also leans heavily on co-financed European rural development funds. In the Netherlands, 'physical architecture' is strong as the capacities and budgets of water managers (regional water boards, national agency Rijkswaterstaat). In Lower Saxony, there is less capacity for technical end of pipe measures as well as stressing effect-based measures. In relation to Assumption B, we think that separated programs and antagonism might lead to more use of 'end-of-pipe' physical architecture when there are capacities to do so, as we have seen in the Netherlands. Denmark and Flanders were using stricter regulatory regimes to address the nutrients problem, but Denmark relaxed its approach while Flanders continues to focus on a program based on 'sticks' (stricter standards, increased enforcement), especially with respect to the focus areas.

\section{Conclusions}

Based on our investigation of the five member states implementing the WFD in view of agricultural diffuse pollution and nutrients, we see that the governance approaches vary a lot, but measures are 
not that different. In this sense our findings do not legitimize strong conclusions on connections between governance characteristics and nature of measures or instruments. First of all, there is no evidence of a direct relationship between organizational separation (on the level of ministries) and nature of measures. This is no surprise, as organizational structures can have other reasons for integration or separation and change in time. Second, we do see connections between consensus-based approaches-and relatively integrated programs- and a greater variety of measures, and some more emphasis on stricter, source based measures. This was confirmed particularly in Ireland and Flanders, although those measures are limited (see Sections 4 and 5). Third, we saw a relationship between program separation and antagonism leading to more effect-based measures, confirmed in Lower Saxony and the Netherlands. In Denmark, the nature of measures and instruments changed in time, as was explained in Sections 4 and 5.

We could expect that a consensus-based and possibly integrated approach leads to a variety of measures, including source-based, but mostly on a voluntary basis, like in Ireland. More remarkable was the case of Flanders, where a consensus-based approach (between environment, water and agriculture) and relative program integration of water management and agriculture was combined with a regulatory regime including mandatory source based measures. The agricultural representatives accepted such stricter regulation as it was area-specific, focusing on the regions with intensive livestock and manuring practices and not applying to farmers in all regions.

If we consider our findings in a broader perspective than the factors now discussed, we could undoubtedly include more variables of importance that determine the nature of the measures taken. One candidate would be the capacities of water managers to take certain measures, either effect-based measures such as technical measures to dephosphatate or cleanse surface water, or capacities for stronger monitoring, enforcement and regulatory measures (cf. [6]). The Netherlands has developed strong capacities in technical measures as direct provisioning of water treatment. Flanders, for example, has over the years created strong capacities to both have administrative control ánd enforcement in the field and thus knows its addressees (mainly farmers and transport) in the focus areas where a regulatory regime has become important. National agents in Ireland also have a great potential to create systems of control, but prefer to invest mostly in a voluntary approach.

Obviously, broad comparisons such as we presented here, have analytical and empirical flaws. The problem pressure is never exactly the same in each country or region. Timing may also be important. For example Ireland has created a new approach recently that has not provided any evidence base on outcomes yet, while other countries have been struggling with the wicked problem of nutrients for decades and have institutionalized policies. There are a wide range of varieties in the governance discourse on collaboration (in this case, between water and agriculture), as well as the substantial discourse on the importance of a good water quality for agriculture. In Ireland, statements were used, such as 'water quality is the new milk quota' (Interview ministry Environment, March, 2018), or in other words, water quality is seen a condition for agricultural development rather than a side effect. However, governance collaboration and program integration is no panacea for better mixes of measures. As we have seen, relatively consensual, integrated programs may lead to different strategies in terms of mandatory or voluntary measures.

In conclusion, dealing with a serious wicked problem, such as diffuse pollution and nutrients with a discretionary and experimentalist governance approach [29] might produce informed, nuanced and tailor-made programs of measures, perhaps combined with all kinds of voluntary and subsidized measures, which could work. Yet it could just as well lead to situations where the core of the problem of nutrients pollution are not addressed leading to decline inefficiency so that the goals of the WFD are not achieved or significantly diminished. In either case, it is wise to have a critical look at potential measures and political choices made, while acknowledging that every region or member state will create, culturally, politically and organizationally the most appropriate design of policies, instruments and measures. From both, a normative point of view and in view of efficiency for the WFD, the challenge is to find the balance between taking source-based measures where necessary and 
accommodating the difficult situation farmers very often find themselves in. The reduction of nutrients use (as a source-based measure) can lead to lower yields and higher costs for manure disposal.

Author Contributions: Conceptualization, M.W. and D.B.; funding acquisition, M.W. and D.L.; Investigation, M.W., D.L., D.B., A.C., M.K. and N.K.; project administration, M.W., D.L. and D.B.; writing—original draft, M.W., D.L., D.B. and M.K.; Writing-review and editing, M.W., D.L., D.B., A.C. and N.K. All authors have read and agreed to the published version of the manuscript.

Funding: This research received no external funding.

Acknowledgments: The two research projects that form the basis of this article $[10,75]$ were supported by the Netherlands Environmental Assessment Agency (PBL).

Conflicts of Interest: The authors declare no conflict of interest.

\section{Appendix A}

Table A1. List Interview Respondents Comparative Study WFD (Made Anonymous).

\begin{tabular}{|c|c|}
\hline Time & Organization \\
\hline & Denmark \\
\hline February 2018 & Kommunernes Landsforening (Local Government Denmark), Copenhagen \\
\hline February 2018 & Landbrug og Fødevarer (Danish Agriculture and Food Council), Copenhagen \\
\hline February 2018 & Danmarks Naturfredningsforening (Danish Nature), Copenhagen \\
\hline \multirow[t]{2}{*}{ February 2018} & $\begin{array}{c}\text { Miljø- og Fødevareministeriet (Ministry of Environment and Food of Denmark), } \\
\text { Copenhagen }\end{array}$ \\
\hline & Lower Saxony \\
\hline February 2018 & $\begin{array}{l}\text { Niedersächsischer Landesbetrieb für Wasserwirtschaft, Küsten- und Naturschutz, } \\
\text { NLWKN, Meppen office }\end{array}$ \\
\hline February 2018 & Wasserverbandstag Bremen/Niedersachsen/Sachsen-Anhalt, Hannover \\
\hline February 2018 & Bundesministerium für Umwelt, Naturschutz, Bau und Reaktorsicherheit, Bonn \\
\hline February 2018 & Kommunale Umwelt-Aktion; Niedersächsischer Städte- und Gemeindebund, Hannover \\
\hline March 2018 * & NABU Niedersachsen e.V., Fachbereichsleitung Naturschutz \\
\hline February 2018 & Niedersächsisches Ministerium für Umwelt, Energie, Bauen und Klimaschutz, Hannover \\
\hline \multirow[t]{2}{*}{ February 2018} & Landwirtschaftskammer, Oldenburg \\
\hline & Flanders \\
\hline February 2018 & $\begin{array}{l}\text { Coördinatiecentrum Voorlichting en Begeleiding duurzame Bemesting (CVBB), } \\
\text { Sint-Katelijne-Waver }\end{array}$ \\
\hline February 2018 & Universiteit Antwerpen, Antwerpen \\
\hline February 2018 & Boerenbond, Leuven \\
\hline February 2018 & Vlaamse Landmaatschappij, Brussel \\
\hline March $2018^{*}$ & Vlaamse Milieumaatschappij \\
\hline February 2018 & Provincie Antwerpen, dienst integraal waterbeleid, Antwerpen \\
\hline February 2018 & Minaraad, Brussel \\
\hline February 2018 & $\begin{array}{l}\text { Vlaams Departement Landbouw \& Visserij, Brussel } \\
\text { Ireland }\end{array}$ \\
\hline March 2018 & Environmental Protection Agency, Wexford \\
\hline March 2018 & Department of Political Science and Sociology of National University of Ireland, Galway \\
\hline March 2018 & $\begin{array}{c}\text { Principal Officer and Water policy advisor, Department of Housing, Planning and Local } \\
\text { Government, Wexford }\end{array}$ \\
\hline March 2018 & Heritage Officer at An Taisce, Sustainable Water Network Ireland, Dublin \\
\hline March 2018 & Irish Farmers' Association (IPA), Dublin \\
\hline March 2018 & Regional coordinator Waters and Communities Officers (LAWCO), Dublin \\
\hline
\end{tabular}

* Following the workshop, members of the two Regional Water Authorities were asked to provide detailed comments on the draft of chapter 5 'Conclusion: key themes and scenarios for the Netherlands'. 


\section{Appendix B}

Table A2. Organizations in International Workshop-12 April 2018 (Made Anonymous).

\begin{tabular}{c}
\hline Niedersächsischer Landesbetrieb für Wasserwirtschaft, Küsten- und Naturschutz (NLWKN) \\
Netherlands Environmental Assessment Agency \\
Union of Regional Water Authorities \\
University of Antwerp \\
Deutscher Bund der verbandlichen Wasserwirtschaft; \\
(European Union of Water Management Associations) \\
Projectbureau KRW-DHZ Maasregio \\
Regional Water Authority Aa en Maas \\
Ministerie van Infrastructuur en Waterstaat (Ministry of Infrastructure and Water) \\
Aarhus University \\
Regional Water Authority Brabantse Delta \\
Netherlands Environmental Assessment Agency \\
Radboud University Nijmegen, 4 persons
\end{tabular}

\section{Appendix C}

Table A3. List of Interviewees Dutch Report (Made Anonymous).

\begin{tabular}{cc}
\hline Datum & Organization \\
\hline $11-9-2018$ & Program bureau KRW/DHZ \\
$18-9-2018$ & ORG-ID \\
$19-9-2018$ & LTO Noord \\
$1-10-2018$ & Regional Water Authority Amstel Gooi Vecht \\
$1-10-2018$ & Regional Water Authority Amstel Gooi Vecht / waternet \\
$2-10-2018$ & Province Drenthe \\
$2-10-2018$ & Kadaster \\
$4-10-2018$ & ZLTO \\
$4-10-2018$ & Brabantse Milieufederatie \\
$8-10-2018$ & Regional Water Authority Hunze en Aa's \\
$10-10-2018$ & Regional Water Authority Aa en Maas \\
$15-10-2018$ & LTO Glaskracht (agriculture) \\
$16-10-2018$ & Water board Hunze en Aa's \\
$16-10-2018$ & Province Groningen \\
$16-10-2018$ & Province Groningen \\
$22-11-2018$ & Regional Water Authority Delfland with 4 interviewees \\
\hline
\end{tabular}

\section{Appendix D}

Table A4. Participants Reflection Workshop 6 February 2019 (Made Anonymous).

\begin{tabular}{c} 
Organization \\
\hline Regional Water Authority Aa en Maas \\
ORG-ID \\
Utrecht University \\
PBL /Netherlands Environmental Assessment Agency \\
PBL/Netherlands Environmental Assessment Agency \\
Program bureau Maas \\
Rijkswaterstaat/core team Deltaprogram Agricultural Water Management DAW \\
Regional Water Authority Hollands Noorderkwartier \\
Regional Water Authority Schieland en de Krimpenerwaard \\
Radboud University, 3 persons
\end{tabular}




\section{References}

1. Maia, R. The WFD implementation in the European member states. Water Resour. Manag. 2017, 31, 3043-3060. [CrossRef]

2. Voulvoulis, N.; Arpon, K.D.; Giakoumis, T. The EU Water Framework Directive: From great expectations to problems with implementation. Sci. Total Environ. 2017, 575, 358-366. [CrossRef] [PubMed]

3. Giakoumis, T.; Voulvoulis, N. Progress with monitoring and assessment in the WFD implementation in five European river basins: Significant differences but similar problems. Eur. J. Environ. Sci. 2018, 8, 44-50. [CrossRef]

4. EEA European Waters Assessment of Status and Pressures 2018; European Environmental Agency: Copenhagen, Denmark, 2018.

5. Gunningham, N.; Sinclair, D. Policy instrument choice and diffuse source pollution. J. Environ. Law 2005, 17, 51-81. [CrossRef]

6. Patterson, J.J.; Smith, C.; Bellamy, J. Understanding enabling capacities for managing the 'wicked problem' of nonpoint source water pollution in catchments: A conceptual framework. J. Environ. Manag. 2013, 128, 441-452. [CrossRef] [PubMed]

7. Liefferink, D.; Wiering, M.; Uitenboogaert, Y. The EU water framework directive: A multi-dimensional analysis of implementation and domestic impact. Land Use Policy 2011, 28, 712-722. [CrossRef]

8. Bourblanc, M.; Crabbé, A.; Liefferink, D.; Wiering, M. The marathon of the hare and the tortoise: Implementing the EU Water Framework Directive. J. Environ. Plan. Manag. 2013, 56, 1449-1467. [CrossRef]

9. Boeuf, B.; Fritsch, O. Studying the implementation of the Water Framework Directive in Europe: A meta-analysis of 89 journal articles. Ecol. Soc. 2016, 21, 19. [CrossRef]

10. Wiering, M.; Liefferink, D.; Kaufmann, M.; Kurstjens, N. Final Report: The Implementation of the Water Framework Directive, a Focused Comparison of Governance Arrangements to Improve Water Quality; Radboud University, Institute for Management Research: Nijmegen, The Netherlands, 2018. Available online: https://repository.ubn.ru.nl/bitstream/handle/2066/199699/199699pub.pdf (accessed on 7 October 2019).

11. Newig, J.; Pahl-Wostl, C.; Sigel, K. The role of public participation in managing uncertainty in the implementation of the Water Framework Directive. Eur. Environ. 2005, 15, 333-343. [CrossRef]

12. Newig, J.; Koontz, T.M. Multi-level governance, policy implementation and participation: The EU's mandated participatory planning approach to implementing environmental policy. J. Eur. Public Policy 2014, 21, $248-267$. [CrossRef]

13. Newig, J.; Schulz, D.; Jager, N.W. Disentangling puzzles of spatial scales and participation in environmental governance-The case of governance re-scaling through the European water framework directive. Environ. Manag. 2016, 58, 998-1014. [CrossRef] [PubMed]

14. Moss, T. Spatial fit, from panacea to practice: Implementing the EU Water Framework Directive. Ecol. Soc. 2012, 17, 2. [CrossRef]

15. Hering, D.; Borja, A.; Carstensen, J.; Carvalho, L.; Elliott, M.; Feld, C.K.; Solheim, A.L. The European Water Framework Directive at the age of 10: A critical review of the achievements with recommendations for the future. Sci. Total Environ. 2010, 408, 4007-4019. [CrossRef] [PubMed]

16. Dalgaard, T.; Hansen, B.; Hasler, B.; Hertel, O.; Hutchings, N.J.; Jacobsen, B.H.; Jensen, L.S.; Kronvang, B.; Olesen, J.E.; Schjørring, J.; et al. Policies for agricultural nitrogen management-Trends, challenges and prospects for improved efficiency in Denmark. Environ. Res. Lett. 2014, 9, 115002. [CrossRef]

17. Van Grinsven, H.J.M.; Tiktak, A.; Rougoor, C.W. Evaluation of the Dutch implementation of the nitrates directive, the water framework directive and the national emission ceilings directive. NJAS-Wageningen J. Life Sci. 2016, 78, 69-84. [CrossRef]

18. Hovik, S. Integrated Water Quality Governance and Sectoral Responsibility: The EU Water Framework Directive's Impact on Agricultural Sector Policies in Norway. Water 2019, 11, 2215. [CrossRef]

19. Van Grinsven, H.J.M.; Ten Berge, H.F.M.; Dalgaard, T.; Fraters, B.; Durand, P.; Hart, A.; Osterburg, B. Management, regulation and environmental impacts of nitrogen fertilization in northwestern Europe under the Nitrates Directive: A benchmark study. Biogeosciences 2012, 9, 5143-5160. [CrossRef]

20. Gault, J.; Guillet, M.; Hubert, C.; Paulin, F.; Soulié, M.C. Analysis of Implementation of the Nitrates Directive by other Member States of the European Union; Ministry of Ecology, Sustainable Development and Energy: Paris, France, 2015; p. 149. 
21. Scientific Committee on Nutrient Management Policy Advies Commissie Deskundigen Meststoffenwet "Analyse mestbeleid in andere EU-landen"-Wettelijke Onderzoekstaken Natuur en Milieu; Wageningen University and Research: Wageningen, The Netherlands, 2019.

22. Kastens, B.; Newig, J. The Water Framework Directive and agricultural nitrate pollution: Will great expectations in Brussels be dashed in Lower Saxony? Eur. Environ. 2007, 17, 231-246. [CrossRef]

23. Wiering, M.; Boezeman, D.; Crabbé, A. The Water Framework Directive and agricultural diffuse pollution: Fighting a running battle? How are countries integrating water quality management with agricultural policies in light of clean and healthy waters in Europe? Water 2020, in press.

24. ECA (European Court of Auditors). Special Report. Integration of EU Water Policy Objectives with the CAP: A Partial Success; European Court of Auditors: Brussels, Belgium, 2014. Available online: http: //www.eca.europa.eu/Lists/ECADocuments/SR14_04/SR14_04_EN.pdf (accessed on 25 February 2020).

25. ECA (European Court of Auditors). Greening: A More Complex Income Support Scheme, Not Yet Environmentally Effective; European Court of Auditors: Brussels, Belgium, 2017. Available online: https://www.eca.europa.eu/ Lists/ECADocuments/SR17_21/SR_GREENING_EN.pdf (accessed on 25 February 2020).

26. Carvalho, L.; Mackay, E.B.; Cardoso, A.C.; Baattrup-Pedersen, A.; Birk, S.; Blackstock, K.L.; Borics, B.; Borja, A.; Feld, C.; Ferreira, M.T.; et al. Protecting and restoring Europe's waters: An analysis of the future development needs of the Water Framework Directive. Sci. Total Environ. 2019, 658, 1228-1238. [CrossRef]

27. Capano, G.; Howlett, M. The Knowns and Unknowns of Policy Instrument Analysis: Policy Tools and the Current Research Agenda on Policy Mixes. Sage Open 2020. [CrossRef]

28. Poikane, S.; Zampoukas, N.; Borja, A.; Davies, S.P.; van de Bund, W.; Birk, S. Intercalibration of aquatic ecological assessment methods in the European Union: Lessons learned and way forward. Environ. Sci. Policy 2014, 44, 237-246. [CrossRef]

29. Sabel, C.F.; Zeitlin, J. Experimentalist Governance. In The Oxford Handbook of Governance; Levi-Faur, D., Ed.; Oxford University Press: Oxford, UK, 2012; pp. 169-183.

30. Van Eerd, M.M.C.J.; Wiering, M.M.A.; Dieperink, C.C. Policy discretion, adaptation pressure and reloading implementation experiences in EU water governance: The case of the Netherlands. Water Altern. 2019, 12, 886-906.

31. Wernersson, A.S.; Carere, M.; Maggi, C.; Tusil, P.; Soldan, P.; James, A.; Buchinger, S. The European technical report on aquatic effect-based monitoring tools under the water framework directive. Environ. Sci. Eur. 2015, 27, 7. [CrossRef]

32. Lascoumes, P.; Le Galès, P. Understanding Public Policy through its Instruments. Governance 2007, 20 , 1-144. [CrossRef]

33. Flanagan, K.; Uyarra, E.; Laranja, M. Reconceptualising the 'policy mix' for innovation. Res. Policy 2011, 40, 702-713. [CrossRef]

34. Bressers, H.T.A.; O'Toole, L.J., Jr. Instrument selection and implementation in a networked context. In Designing Government: From Instruments to Governance; Eliades, P., Hill, M.M., Howlett, M., Eds.; Montreal\&Kingston: London, UK; McGill-Quenn's University Press: Ithaca, NY, USA, 2005; pp. 132-153.

35. Hood, C. Intellectual obsolescence and intellectual makeovers: Reflections on the tools of government after two decades. Governance 2007, 20, 127-144. [CrossRef]

36. Collins, A.L.; Price, J.N.; Zhang, Y.; Gooday, R.; Naden, P.S.; Skirvin, D. Assessing the potential impacts of a revised set of on-farm nutrient and sediment 'basic' control measures for reducing agricultural diffuse pollution across England. Sci. Total Environ. 2018, 621, 1499-1511. [CrossRef] [PubMed]

37. Bemelmans-Videc, M.L.; Rist, R.C.; Vedung, E. Carrots, Sticks and Sermons: Policy Instruments and Their Evaluation; Transaction Publishers: New Brunswick, NJ, USA, 1998.

38. Bergevoet, R.; Bondt, N.; de Lauwere, C.; Buurma, J.; Linderhof, V.; Rijk, P. Financiële Prikkels in de Landbouw Voor Verbetering van de Waterkwaliteit (No. 2016-033); LEI Wageningen UR: Wageningen, The Netherlands, 2016.

39. Hoogerwerf, A.; Herweijer, M. Overheidsbeleid. In Een Inleiding in de Beleidswetenschap; Kluwer: Alphen aan de Rijn, The Netherlands, 2008; pp. 223-238.

40. Uitenboogaart, Y.; Van Kempen, J.J.H.; Wiering, M.; Van Rijswick, H.F.M.W. (Eds.) Dealing with Complexity and Policy Discretion, a Comparison of the Implementation of the Water Framework Directive in Five Member States; Sdu Uitgevers: The Hague, The Netherlands, 2009.

41. Richardson, J.J.; Gustafsson, G.; Jordan, G. The Concept of Policy Style. In Policy Styles in Western Europe; Richardson, J.J., Ed.; George Allen and Unwin: London, UK, 1982; pp. 1-16. 
42. Van Waarden, F. 'Persistence of National Policy Styles: A Study of Their Institutional Foundations'. In Convergence or Diversity? Internationalization and Economic Policy Response; Unger, B., van Waarden, F., Eds.; Aldershot: Avebury, UK, 1995; pp. 333-372.

43. Visseren-Hamakers, I.J. Integrative environmental governance: Enhancing governance in the era of synergies. Curr. Opin. Environ. Sustain. 2015, 14, 136-143. [CrossRef]

44. 44. Weitz, N.; Strambo, C.; Kemp-Benedict, E.; Nilsson, M. Closing the governance gaps in the water-energyfood nexus: Insights from integrative governance. Glob. Environ. Chang. 2017, 45, 165-173. [CrossRef]

45. Van Steertegem, M. (Ed.) Milieurapport Vlaanderen. Indicatorrapport 2012; Vlaamse Milieumaatschappij: Aalst, Belgium, 2013.

46. MIRA Indicatoren Waterkwaliteit. Overview of Indicators on Water Quality in Flanders. 2020. Available online: https://www.milieurapport.be/milieuthemas/waterkwaliteit\#toc-definition (accessed on 9 February 2020).

47. Andersen, M.S. Denmark: The shadow of the green majority. In European Environmental Policy. The Pioneers; Andersen, M.S., Liefferink, D., Eds.; Manchester University Press: Manchester, UK, 1997; pp. 251-286.

48. Jacobsen, B.H.; Anker, H.T.; Baaner, L. Implementing the water framework directive in Denmark-lessons on agricultural measures from a legal and regulatory perspective. Land Use Policy 2017, 67, 98-106. [CrossRef]

49. Thorsøe, M.; Dalgaard, T.; Graversgaard, M. Nabotjek af Kvælstof-og Fosforvirkemidler; Aarhus Universitet, Institut for Agroøkologi: Aarhus, Denmark, 2017.

50. Wright, S.A.; Jacobsen, B.H. Participation in the implementation of the Water Framework Directive in Denmark: The prospects for active involvement. Water Policy 2011, 13, 232-249. [CrossRef]

51. Thorsøe, M.H.; Graversgaard, M.; Noe, E. The challenge of legitimizing spatially differentiated regulation: Experiences from the implementation of the Danish Buffer zone act. Land Use Policy 2017, 62, $202-212$. [CrossRef]

52. Anker, H.T. Agricultural nitrate pollution: Regulatory approaches in the EU and Denmark. Nord. Miljoeraettslig Tidskr. 2015, 2, 7-23.

53. Ministry of Environment and Food of Denmark/EPA. Overview of the Danish Regulation of Nutrients in Agriculture \& the Danish Nitrates Action Programme; Ministry of Environment and Food of Denmark/EPA: Copenhagen, Denmark, 2017; Available online: http://eng.mst.dk/media/186211/overview-of-the-danishregulation-of-nutrients-in-agriculture-the-danish-nitrates-action-programme.pdf (accessed on 8 January 2018).

54. Van Gaalen, F.V.; Tiktak, A.; Franken, R.; Boekel, E.V.; Puijenbroek, P.V.; Muilwijk, H.; Groenendijk, P. Waterkwaliteit nu en in de Toekomst: Eindrapport ex ante Evaluatie van de Nederlandse Plannen voor de Kaderrichtlijn Water: Beleidsstudie; Planbureau voor de Leefomgeving: The Hague, The Netherlands, 2016; p. 1727.

55. Groenendijk, P.; van Boekel, E.M.P.M. Agriculture and WFD Reduction Targets for Nutrients in Regional Waters. 2017. Available online: https://library.wur.nl/WebQuery/wurpubs/532916 (accessed on 24 April 2020).

56. Van der Heijden, J.; ten Heuvelhof, E.; Broekhans, B.; van der Arend, S.; van Bueren, E.; Harteveld, C.; van Ruijven, T. Contrasting stories on overcoming governance challenges: The implementation of the EU Water Framework Directive in the Netherlands. Local Environ. 2014, 19, 318-333. [CrossRef]

57. Van der Vlies, A.; Krom, D.; Madlener, K. Tweede Kamerstukken (Dutch Parliament) 2006-2007, 27625 nr. 92, 28-06-2007. Available online: https://zoek.officielebekendmakingen.nl/kst-27625-92.html (accessed on 24 April 2020).

58. Boezeman, D.F.; Liefferink, J.D.; Wiering, M.A. De governance van de Kaderrichtlijn Water, regionale verschillen en sturingsopties. Water Gov. 2019, 2019a, 72-81.

59. Frouws, J.; Tatenhove, J.V. Agriculture, Environment and the State. The development of agro-environmental policy-making in the Netherlands. Sociol. Rural. 1993, 33, 220-239. [CrossRef]

60. Schuurman, A. Agricultural policy and the Dutch agricultural institutional matrix during the transition from organized to disorganized capitalism. In Integration through Subordination; Moser, P., Varley, T., Eds.; The politics of agricultural modernisation in industrial, Europe; Brepols: Turnhout, Belgium, 2013; Volume 8, pp. 65-84.

61. Vink, M.; Boezeman, D. Naar een wenkend perspectief voor de Nederlandse landbouw. In Voorwaarden Voor Verandering; Planbureau voor de Leefomgeving: The Hague, The Netherlands, 2018.

62. Keessen, A.M.; Runhaar, H.A.C.; Schoumans, O.F.; Van Rijswick, H.F.M.W.; Driessen, P.P.J.; Oenema, O.; Zwart, K.B. The need for flexibility and differentiation in the protection of vulnerable areas in EU environmental law: The implementation of the Nitrates Directive in the Netherlands. J. Eur. Envrion. Plan. Law 2011, 8, 141-164. 
63. Byrne, C.; Fanning, A. (Eds.) Environmental Protection Agency Water Quality in Ireland 2010-2012; Environmental Protection Agency: Wexford, Ireland, 2015.

64. Environmental Protection Agency Ireland's Environment_-An Assessment 2016; Environmental Protection Agency: Wexford, Ireland, 2016.

65. Daly, D.; Deakin, J.; Craig, M.; Mockler, E.M. Progress in implementation of the Water Framework Directive in Ireland. In Proceedings of the International Association of Hydrogeologists (IAH) (Irish Group) Conference Sustaining Ireland's Water Future: The Role of Groundwater, Tullamore, Ireland, 12-13 April 2016.

66. Department of Housing, Planning, Community and Local Government Public Consultation on the River Basin Management Plan for Ireland (2018-2021); Department of Housing, Planning, Community and Local Government: Dublin, Ireland, 2017.

67. LAWCO Waters \& Communities. Healthy Waters Supporting Vibrant Communities.Brochure Local Authority Waters and Communities Office, 2017. Available online: http://watersandcommunities.ie (accessed on 26 April 2018).

68. Department of Housing. Planning and Local Government River Basin Management Plan for Ireland (2018-2021); Department of Housing, Planning, Community and Local Government: Dublin, Ireland, 2018. Available online: https://www.housing.gov.ie/ (accessed on 19 May 2018).

69. Buckley, C.; Wall, D.P.; Moran, B.; O’Neil, S.; Murphy, P.N. Farm gate level nitrogen balance and use efficiency changes post implementation of the EU Nitrates Directive. Nutr. Cycl. Agroecosyst. 2016, 104,1-13. [CrossRef]

70. Irish Farmers' Association Smart Farming, Improving Farm Results. Enhancing the Environment; Progress Report 2017; Irish Farmers' Association (IFA): Dublin, Ireland, 2017.

71. LAWA Prognose der Auswirkung einer nach Gewaesserschutzaspekten Novellierten Duengeverordnung auf die Qualität der Oberflaechengewaesser in Deutschland; LAWA: Husum, Germany, 2014.

72. Niedersächsische Staatskanzlei Nitrat- und Phosphat-Kulisse Ausgewiesen. 2019. Available online: https://www. stk.niedersachsen.de/startseite/presseinformationen/nitrat-und-phosphat-kulisse-ausgewiesen-180478.html (accessed on 19 October 2019).

73. NLWKN Trinkwasserschutzkooperationen in Niedersachsen. Grundlagen des Kooperationsmodells und Darstellung der Ergebnisse; NLWKN: Norden, Germany, 2015.

74. DiMaggio, P.J.; Powell, W.W. The iron cage revisited: Institutional isomorphism and collective rationality in organizational fields. Am. Sociol. Rev. 1983, 48, 147-160. [CrossRef]

75. Boezeman, D.F.; Liefferink, D.; Wiering, M. Nieuwe Richtingen Voor de Implementatie van de Kaderrichtlijn Water. In Regionale Governance Verschillen en Sturingsvarianten Voor de Toekomst; Eindrapportage. Planbureau voor de Leefomgeving: The Hague, The Netherlands, 2019. 